\title{
THE SPATIAL PATTERNS OF DAIRY FARMING IN MOLISE
}

\section{Corrado levoli ${ }^{1}$, Roberto Basile ${ }^{2}$, Angelo Belliggiano ${ }^{3}$}

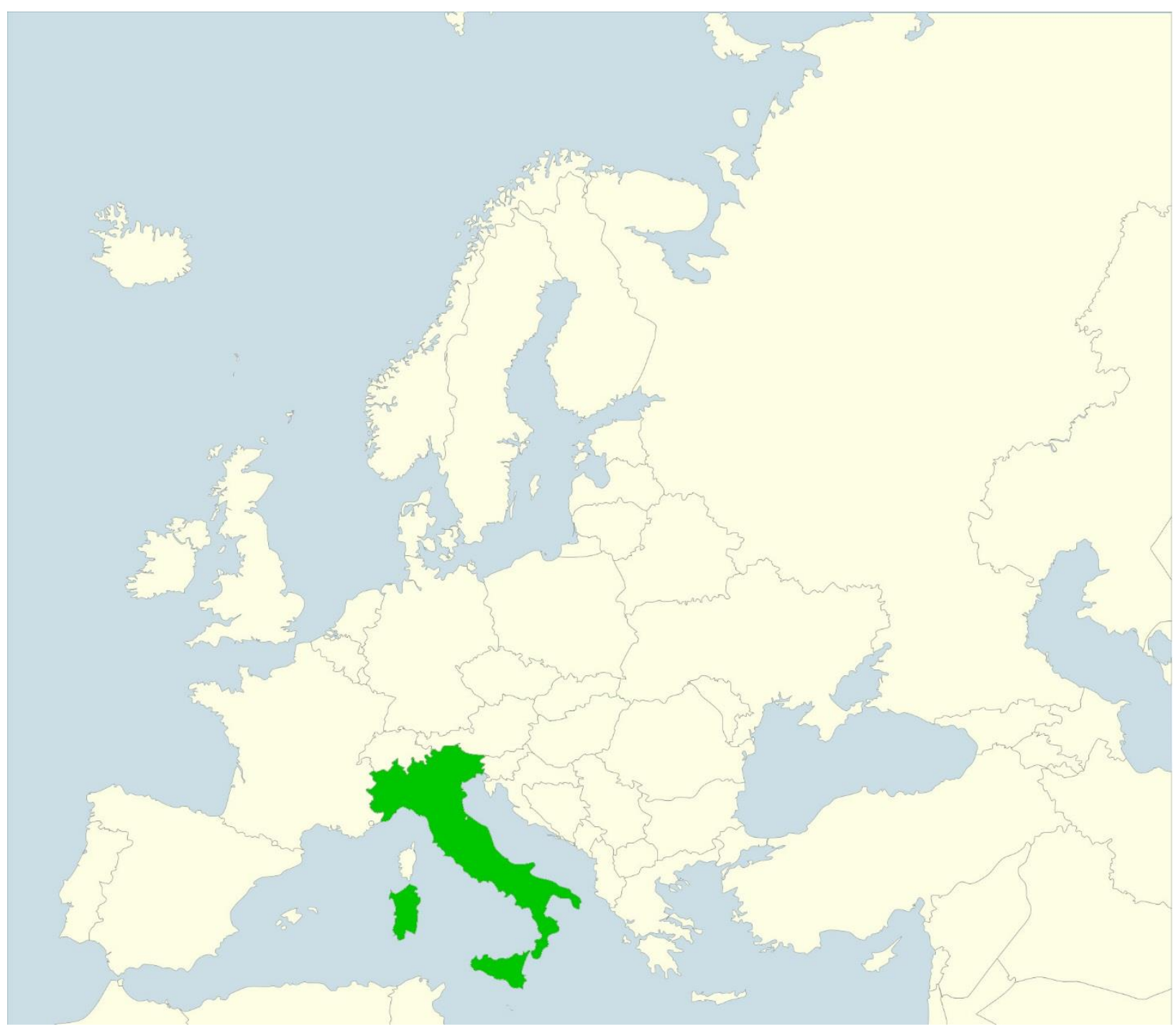

1 Prof. Corrado levoli, Dipartimento Agricoltura Ambiente Alimenti, Università del Molise, via de Sanctis III Polifunzionale, 86100 Campobasso, Italia, email: ievoli@unimol.it

2 Prof. Roberto Giovanni Basile, Dipartimento di Economia, Università degli studi della Campania "Luigi Vanvitelli", Corso Gran Priorato di Malta 1, 81043, Capua, Italia, email: roberto.basile@unina2unicampania.it.

3 Prof. Angelo Belliggiano, Dipartimento Agricoltura Ambiente Alimenti, Università del Molise, via de Sanctis III Polifunzionale, 86100 Campobasso, Italia, email: belliggi@unimol.it. 
Abstract: The greater market orientation of European dairy production, caused by the end of quota regime, is likely to have consequences on less favoured areas, where breeding of dairy cattle plays both a crucial socio-economic and environmental role. Within this new framework, endogenous factors determining spatial reorganisation of the sector are becoming of increasing relevance. Based on these considerations, this study analyses the impact of the three broader classes of location determinants suggested by economic theory - factor endowment, market potential, and spatial agglomeration externalities - on the spatial pattern of milk production in Molise, a rural region in the south of Italy. Milk production is measured in term of dairy cows per hectare. The truncated distribution of this variable and its high degree of spatial autocorrelation prompted us to apply a Spatial Autoregressive Tobit model. Estimation results reveal that all three categories have a positive effect on the location of milk production, even if the influence of factor endowment (intended as forage area), and market potential (measured in term of proximity of dairy companies) is quite limited. On the contrary, the impact of spatial externalities (related variety) on the regional localisation of milk production is strongly significant. These results cast some doubts on the current measures of intervention and might suggest a new policy framework both at firm and spatial level.

Keywords: Dairy farming; spatial patterns; SAR Tobit model; Sustainable breeding systems; Extensive farming in rural areas.

Sommario: II maggior orientamento al mercato della produzione lattiera europea, dovuto alla fine del regime delle quote, rischia di avere forti ripercussioni sulle aree meno favorite, dove l'allevamento da latte svolge un ruolo cruciale da un punto di vista socioeconomico ed ambientale. In questo nuovo quadro, i fattori endogeni che determinano i processi di riorganizzazione territoriale del comparto assumono maggiore rilievo. Partendo da queste considerazioni, il lavoro analizza l'impatto delle tre grandi categorie di fattori postulate dalla teoria economica (la dotazione di fattori specifici, il potenziale di mercato e le economie di agglomerazione) sulla distribuzione spaziale della produzione di latte in Molise, una regione prevalentemente rurale dell'Italia meridionale. La produzione di latte è misurata in termini di vacche per ettaro. Data la natura troncata di questa variabile ed il suo alto grado di autocorrelazione spaziale, il lavoro utilizza un modello SAR Tobit. I risultati ottenuti mostrano che tutte e tre le categorie citate esercitano un'influenza sulla distribuzione spaziale della produzione lattiera, anche se l'importanza della dotazione di fattori specifici (intesi come produzione foraggera) e del mercato potenziale (misurato in termini di vicinanza alle industrie di trasformazione) appare abbastanza limitata. Al contrario le esternalità spaziali, misurate in termini di related variety, sembrano determinare in maniera fortemente significativa la localizzazione della produzione di latte a livello regionale. Questi risultati sollevano perplessità sulle misure di intervento attualmente in vigore e suggeriscono, per le aree marginali, diverse strategie di azione a livello aziendale e territoriale.

Parole chiave: Allevamento da latte; pattern spaziale, modello SAR Tobit; Allevamenti sostenibili; Agricoltura estensiva in aree rurali

\section{Introduction}

Since the end of milk quota regime in 2015, the European dairy sector has experienced a substantial market orientation. This process is expected to exacerbate the intense reorganisation of the production system within this sector observed during the last decade, which 
was mainly driven by economies of scale and productivity growth. ${ }^{4}$ The subsequent ongoing "industrialisation" of livestock production (Thornton, 2010) is expected to have asymmetric consequences across regions. In particular, this process might harm peripheral regions in Europe, where dairy farming differs from the typical high input/output system (CEAS 2000) characterising the industrialised model. In other words, a more market-oriented system will most probably quicken the spatial reorganisation of dairy production in Europe to the detriment of less-favoured areas.

The European Union (EU) is aware of these problems. It is well known that, before the end of milk quotas, the EU adopted the so-called "Milk Package", a set of measures designed to boost the position of dairy producers (written contracts, negotiation via producers' organisations, regulation of supply for $\mathrm{PDO} / \mathrm{PGI}$, rules for inter-branch organisations, transparency and information). In the same Regulation (No 1308/2013), it was established (art 225) that the Commission must report to the Council and to the European Parliament on the development of the market situation, "assessing in particular the effects on milk producers and milk production in disadvantaged regions in connection with the general objective of maintaining production in such regions". Contemporaneously, the European Parliament adopted a resolution on maintaining milk production in mountainous and disadvantaged areas, especially where "the local community depends heavily on the dairy sector". To avoid depopulation of these areas, the European Parliament conveniently recommended using the first and second pillar of the CAP (e.g. grazing premium and specific rural development program for milk production) ${ }^{5}$.

Without prejudice of these recommendations and leaving aside if and how they have been followed, it is worth noting that in such a "new" phase, endogenous factors (such as market dynamics and factors' endowments) may play a greater role in the aforementioned spatial reorganisation. Therefore, to develop effective intervention measures, it becomes relevant to conduct an in-depth analysis of the determinants of the current spatial pattern in dairy farming. In other words, to understand these determinants, it can be important for adjusting interventions in those less-favoured areas where the sector plays a crucial role in the rural system.

Only in the most recent literature has the spatial evolution of dairy farming been considered to be an important research topic. There is indeed a heated debate about the key factors affecting this evolution. The present paper aims to contribute to this debate by providing an empirical analysis of the spatial determinants of milk production in Molise, a rural region in Southern Italy. We measured milk production using census data (cow inventory) for 2010 at a municipality level. Our response variable was the number of dairy cows per hectare in the municipality, a censored variable, characterised by the presence of zero values. Moreover, the spatial analysis of this variable reveals that the dairy cow inventory (and, as a result, milk production) tends to be more concentrated in two areas of the Molise region.

Such a spatial pattern can be explained by several factors. In particular, following a comprehensive theoretical framework, factor endowment, market access and agglomeration economies (localisation and urbanisation externalities) are considered as key drivers of the location of dairy milk farms. Following Roe et al. (2002), Isik (2004), and Larue et al. (2007), we used the spatial lag of the dependent variable as a proxy for localisation economies. Thus, we tested our hypotheses using spatial econometric techniques that are commonly adopted for analysing the diffusion of agricultural activities (Bichler et al., 2005; Läpple and Kelley, 2013;

\footnotetext{
4 This reorganisation of the production system has occurred both in Europe and in the USA, but in different ways. In the USA, the number of dairy farms in the last few decades has declined remarkably, the herd size has grown, and large farms have emerged (MacDonald, et al. 2007). In Europe, the level of milk production has remained stable due to the "quota regime", but the number of cows has significantly decreased. Such increase in milk yields has been due to many factors, such as genetic improvement, breeding techniques, optimised diets, better milking methods (Forti et al. 2016).

${ }^{5}$ Furthermore, the European Milk Market Observatory has discussed how to manage the consequences of marketorientation for milk production in disadvantaged regions, considering several topics (mapping of high risk areas/regions and farming systems, introduction of coupled payments, strengthening regional economic resilience, etc.). In the last Report to the European Parliament and the Council (COM(2014) 354 final), the Commission underlines the potential of the new measure for cooperation of Rural Development Programs (support the development of new products and practices, short supply chains and local markets, cooperation of small operators in organising joint work processes and sharing facilities).
} 
Wollni and Andersson, 2014). Specifically, given the characteristics of the response variable, we used a Spatial Autoregressive Tobit model (LeSage and Page, 2009; Qu and Lee, 2013). The approach followed has enabled measurement of the influence of factors considered and to identify their role at firm, area and policy level.

The remainder of the paper is structured as follows. The next section contains a brief review of the related literature, while in section 3 we described the theoretical framework that we used to approach the uneven spatial distribution of milk production. In section 4, we described some relevant characteristics of the Molise region and, in section 5, the spatial pattern of dairy farming. The specification of the econometric model is explained in section 6 and the econometric results are shown in section 7 . In section 8 , we discussed findings and drew conclusions ${ }^{6}$.

\section{Related literature}

Recently, several scholars have analysed the determinants of the spatial organisation of dairy production in different countries. In a review of this literature, Wieck and Mosnier (2010) reported the main evidence from nineteen studies, which investigated the factors ascribable to comparative advantages of dairy farms and to the spatial organisation of dairy industry. Wieck and Mosnier concluded that land characteristics, sunk costs linked to investments in buildings and equipment, and shared infrastructures represent the most relevant factors to be considered from an empirical point of view.

Some of the studies that were considered turned out to be particularly relevant as background for the present study. For example, Peterson (2002), studying the geographic changes of dairy production and marketing in the USA, found a significant influence of the number of dairy plants in proximity to the farm location. In addition, in the case of the USA, Isik (2004) found positive spatial agglomeration effects in the case of dairy cow inventories, but noted that changes in production tended to negatively affect neighbouring counties.

Ben Arfa et al. (2009) analysed the spatial structure of the French dairy sector. They underlined that long-run evolution (decline in the number of farms, increase in dairy cows per farm, increase in milk yield per cow) involve spatial "redistribution", in favour of regions in plain (but with pollution problems), and problems for traditional dairy regions (loss of competitiveness, social desertification, environmental problems). They highlighted that a certain number of factors - such as milk plants and feed plants affected the number of dairy farms per department. Zimmerman and Heckelei (2012) confirmed the relevance of key factors suggested in the literature, in particular economies of scale, path dependency, and milk price, even if the direction of their impact is sometimes ambiguous.

Wieck and Mosnier (2011) used spatial econometric models to analyse correlations between farms, local dairy sector, and local socioeconomic characteristics with the underlying evolution of regional dairy production within some EU countries.

As a final consideration, all the above-mentioned studies adopted large-scale spatial units (county, department, and region in the strictest sense) for the empirical analysis. The only study using a small-scale spatial unit (i.e. the municipality) focused on the spatial distribution of pig production (Larue et al., 2007).

\section{Conceptual framework}

The literature reported above ultimately identify as key determinants of industrial location in the dairy sector, some factors which can be ascribed to one of the three broad classes of determinants suggested in the economic theory, i.e. comparative advantages, market access and other forms of agglomeration economies.

On the one hand, according to the neoclassical international trade theory, regional differences in factor endowments mainly contribute to determining local comparative advantages and,

\footnotetext{
${ }^{6}$ This paper is the result of teamwork among the authors. In detail, they respectively took responsibility for the following sections: C. levoli 1, 2, 5, 8; R. Basile 6; A. Belliggiano 4. R. Basile and C. levoli jointly wrote section 3 and 7.
} 
therefore, regional specialisation and concentration. In our specific analysis, access to cheap local feed production may help explain a higher concentration of dairy production in some areas than in others.

On the other hand, the New Economic Geography (NEG) theory suggests that an uneven spatial distribution of market access encourages firms to concentrate in places with higher market potential, to benefit from increasing returns, and to export goods and services to other regions. ${ }^{7}$ The location of milk production may be affected by market accessibility, that is dairy farms may tend to be located close to their outlet markets, that is close to dairy companies.

The uneven distribution of milk production can also be explained by other positive spatial agglomeration externalities, which are benefits that firms derive from being located close to other economic actors (Neffke et al., 2011). It is customary to distinguish between localisation and urbanisation economies (Glaeser et al., 1992; Henderson et al., 1995; Rosenthal and Strange, 2004; Beaudry and Schiffauerova, 2009). ${ }^{8}$ Using a well-known categorisation that can be traced back to the work of Marshall, location economies may derive from within-sector pecuniary (static) and non-pecuniary (dynamic) externalities. The former refer to cost reductions derived from a specialised labour market pooling (matching between employers and employees) and from the sharing of intermediate inputs, while dynamic externalities refer to local knowledge spillovers (technological learning) (Duranton and Puga, 2004). Positive spatial externalities in milk production mean that the performance of one dairy farm improves when other dairy farms are located nearby. Such results may arise from access to input services (for example insemination, feeding and veterinary services), from diffusion of information and knowledge through producer organisations and farmer advisors, and from the pooling of skilled workers for dairy farms.

Urbanisation economies derive from the existence of a large variety of industries in the local economy (Jacobs, 1969). A diverse industry structure increases the chances of interaction, generation, replication, modification and recombination of ideas and applications across different sectors (between-sectors knowledge spillovers; see Duranton and Puga, 2001, for a formal treatment of this mechanism). In our analysis, this means that the performance of a dairy farm improves when other firms (belonging to other sectors) are located nearby. However, as suggested by Frenken et al. (2007), knowledge spillovers between sectors are best captured by the notion of "related variety". According to Boschma (2005), Boshma and Wenting (2007), Boschma and Frenken (2011), and Boschma and lammarino (2009), indeed, between-sector externalities are more likely to occur if the cognitive distances between the economic agents involved is neither too large to ensure effective learning, nor too small to allow different types of knowledge to be learned. In our analysis, this means that dairy farms may be attracted by the variety of farms (beef farms, sheep breeding and so forth) located nearby ${ }^{9}$.

\section{Milk production in Molise: some stylised facts}

We analysed the spatial distribution of milk production in Molise, a small region of Italy (Figure 1), whose orographic profile is largely mountainous ${ }^{10}$. Its population is fairly small (about 300,000 people) and apart from three small cities (Campobasso, Isernia and Termoli) - it is dispersed over the territory ${ }^{11}$. According to the EU typology, Molise can be classified as a "Predominantly Rural" region.

\footnotetext{
7 These centripetal forces tend to contrast market competition (or centrifugal) forces arising from the concentration of firms and inducing both lower local market prices and higher local factor prices.

${ }^{8}$ Localisation economies apply to industry-specific external economies of scale, which means that there are positive externalities when a firm from a particular industry locates close to other firms from the same industry. Urbanisation economies refer to inter-industry external economies of scale, which means that there are positive externalities when a firm from a particular industry locates close to firms from other technologically related or unrelated industries.

${ }^{9}$ It must be considered that in certain areas beef breeding can be carried out together with milk breading, in extensive holding conditions.

10 Only on the coast this profile appears more regular (the so called "Basso Molise"), but flat areas are very limited.

11 Population density is about 70 inhabitants $/ \mathrm{km}^{2}$.
} 

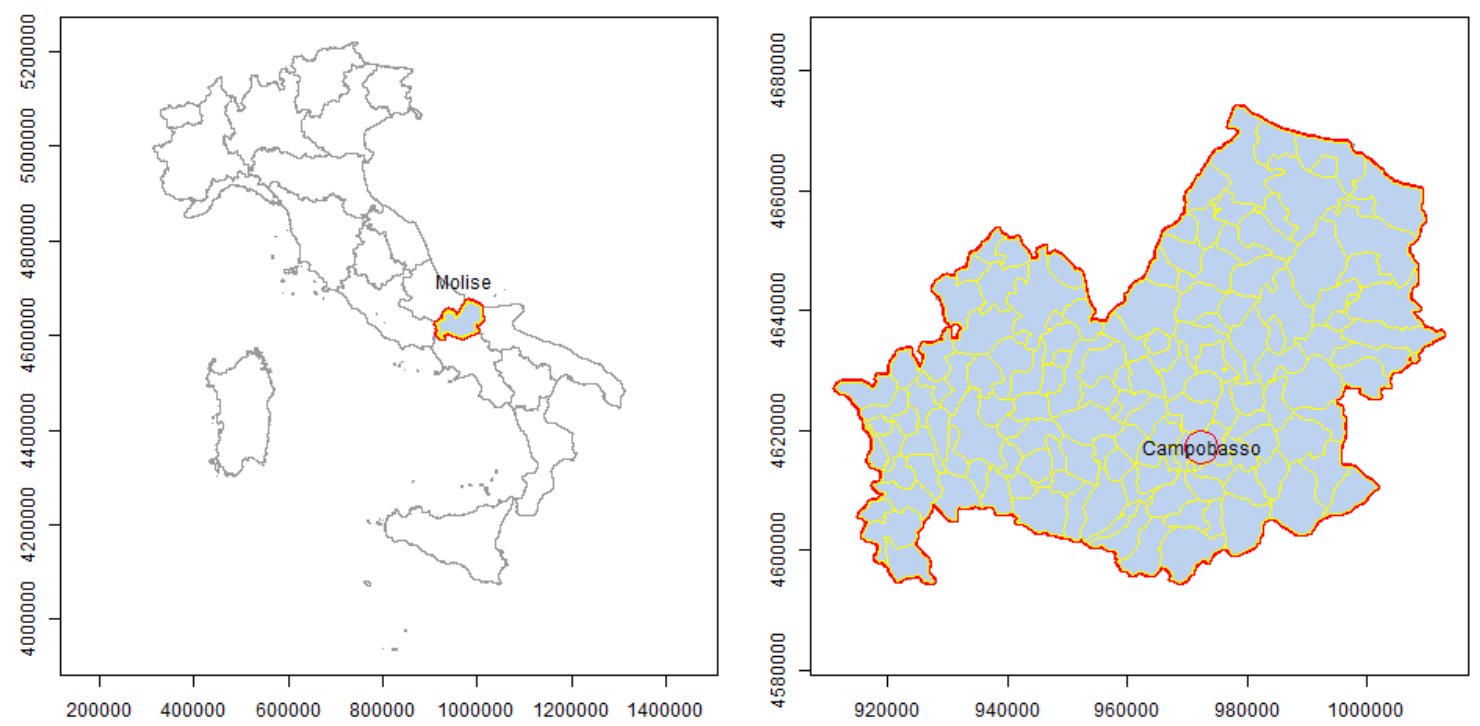

Fig 1. The region of Molise.

Income per capita is lower than the Italian average, but higher than the near less developed regions of Southern Italy. Consequently, for the purposes of the European Regional Policy, Molise as a whole is classified as a "Transition region" (that is a region whose GDP per inhabitant is between $75 \%$ and $90 \%$ of the EU-27 average). However, excluding coastal areas and the three main towns, a large part of the territory is made up of "less favoured areas", characterised by depopulation and by population ageing. Compared to the Italian average, the regional economy shows a considerable labour productivity gap, and is characterised by a high share of agricultural employment on total employment.

From the historical point of view, the predominant agricultural activities (wheat, olive trees, beef breeding, breeding of dairy cattle) have influenced the present composition of the manufacturing industry, still characterised by the preeminent role of food products, such as pasta, olive oil, meat, and cheese. Nevertheless, in the last few decades, new sectors have emerged, in large part not ascribable to agricultural traditions, also in the food industry (Bagarani and Belliggiano, 1997). In the same period, agriculture has witnessed a complex reorganisation - in part linked to CAP evolution (Fasolino and levoli, 1997) that for a long period encouraged the spread of durum wheat, which has led to a redefinition of land use and product specialisation. In the last few years, in fact, the value of livestock production has overtaken the value of that of vegetable crops (Bagarani et al., 2014; Paladino and Scardera 2013). This was mainly caused by the spread of poultry farming, characterised by an industrialised model of breeding linked to "external" value chains, in which the link with local feed is very scarce.

Dairy farming represents an activity historically located in the above mentioned less favoured areas of Molise, where breeding was practised through grazing, and where the (often excellent) milk obtained was processed, often at the same farm, into very high-quality (typical) cheese, that can be considered part of the cultural heritage of these areas. In the last few decades, Molise has shown a decline in the number of dairy farms (from 5,887 in 1982 to 1,332 in 2010). After a significant growth in the 1980's, the number of cows declined as well, to about 16,000 in $2010 .{ }^{12}$ These trends reflect the difficulties faced by the dairy sector in Molise ${ }^{13}$, difficulties that, almost certainly, do not derive from the market performance of final goods made by dairy factories located in Molise. In fact, measured in "milk equivalent" ${ }^{4}$, the production of the regional dairy industry (mainly cheese) is significantly higher than can be achieved using only milk from

\footnotetext{
12 The different dynamics of these phenomena have led to a growth in the number of cows per farm, which nonetheless remains significantly below the Italian average. In other words, also in Molise, economies of scale seemed to work even though this has not led to a growth of milk production.

${ }^{13}$ The implementation of EU schemes concerning hygiene standards, frequently invocated by the main stakeholders, can only partially explain these difficulties.

${ }^{14}$ Milk equivalent, as well known, is a measure of the quantity of fluid milk used in a processed dairy product.
} 
the region. In other words, the current dairy sector in Molise expresses a need for raw milk for a large part met by imported flows (more than 36 million Euros in the last few years, in large part from Germany). On the other hand, the recourse to importing signals the difficulties the local dairy farming sector have experienced in satisfying the above-mentioned requirements both in costs and in security of the supply profile.

\section{The spatial pattern}

The difficulties of dairy farming in Molise must be analysed considering the spatial characteristics of the sector, in particular its location in mountainous areas. Figure 2 shows the spatial reorganisation process of dairy farming in Molise from 1982 to 2010, considering all 136 municipalities. As we can observe, the reported growth of the 1980's seems to have strengthened the spatial spreading of dairy farming expressed in terms of density of cows. Indeed, looking at the map for the year 1990, we can distinguish a large "dark" zone of quasi-contiguous municipalities that goes from North-West - the mountainous area called "Alto Molise" - to the inland territory situated in the Southeast, at the foothills of the mountain chain of Matese. In the same year, municipalities without the presence of milk cows, „zeros”, were very limited, almost sporadic.

The map for the year 2010 displays a very different spatial pattern. The number of zeros has tripled, in particular on the coast side (Basso Molise), but also in Alto Molise. More than a contiguous zone, in 2010 we can observe a "conglomerate" (a pole) in Alto Molise, and a persistent area in the Southeast. In other words, we observed a sort of "drying" of the previous milk farming area, but this was not counterbalanced by a relocation of milk farming in other (more favourable) areas of the region. Structural change in Molise appears mainly as a process of "shutdown" of several municipalities and of restructuring within the focus area.

Table 1 synthesises the main characteristics of our dependent variable, i.e. the number of dairy cows per hectare in the municipalities of Molise.

Tab 1. Number of milk cows per ha. Years: 1982, 1990, 2000, 2010.

\begin{tabular}{|l|l|l|l|l|l|l|}
\hline & Min. & 1st Qu. & Median & Mean & 3rd Qu. & Max. \\
\hline 1982 & 0.000 & 0.011 & 0.043 & 0.080 & 0.104 & 0.485 \\
\hline 1990 & 0.000 & 0.022 & 0.070 & 0.108 & 0.153 & 0.510 \\
\hline 2000 & 0.000 & 0.008 & 0.054 & 0.096 & 0.137 & 0.546 \\
\hline 2010 & 0.000 & 0.000 & 0.048 & 0.086 & 0.125 & 0.763 \\
\hline
\end{tabular}



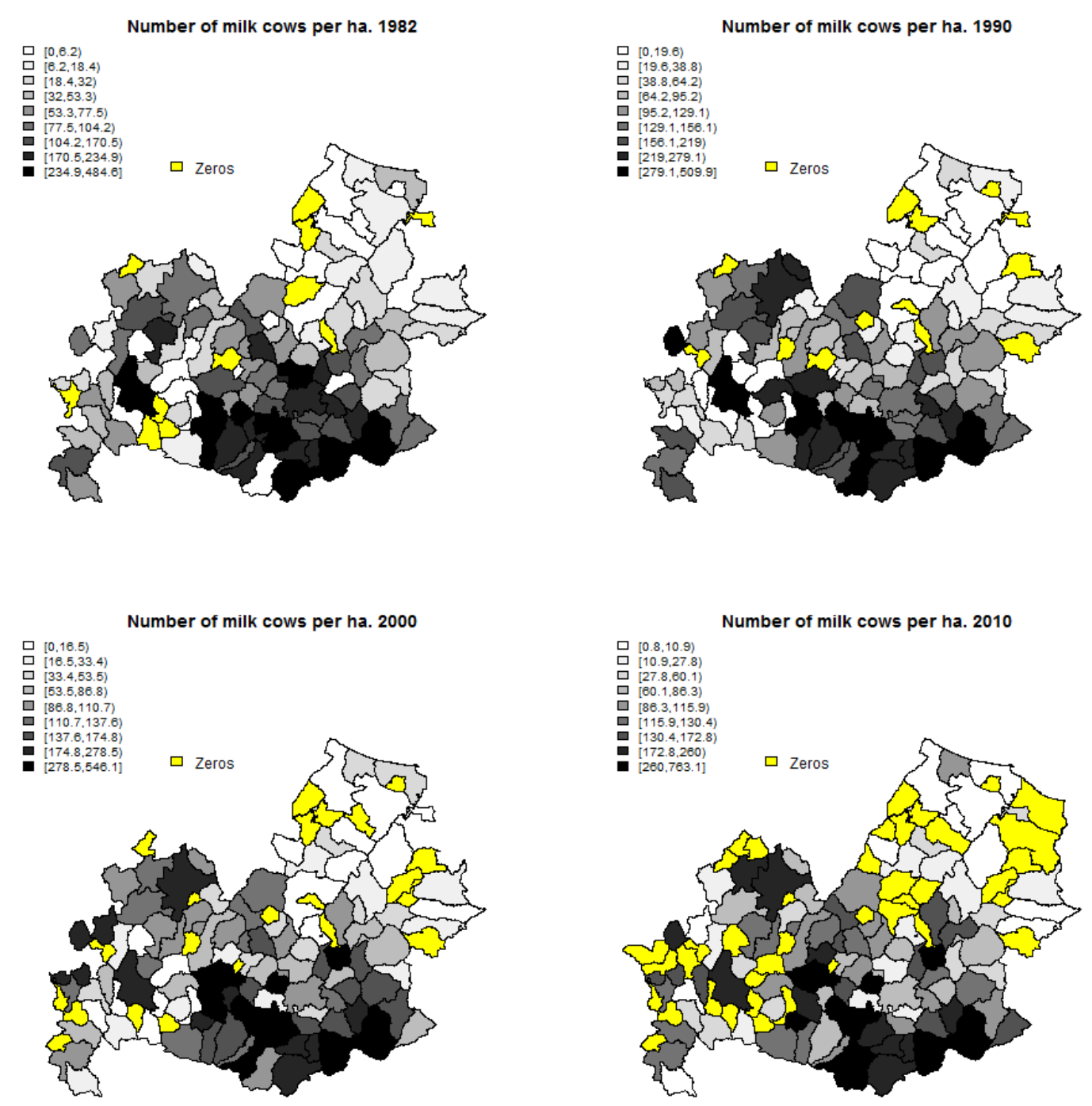

Fig 2. Dairy cows per hectare at municipality level in 1982 and 2010. Source: ISTAT 


\section{Modelling the spatial structure of milk production: a SAR Tobit model}

As shown above, the distribution of our dependent variable is characterised by a number of zero observations (in 39 out of 136 municipalities, the number of dairy cows reported by the census is zero). These represent censored values, which result in a truncated distribution of the dependent variable observations (Figure 3). We argue that these censored values represent municipalities where the utility (profit) associated with raising dairy cows is negative. We must consider this feature in modeling the dependent variable.

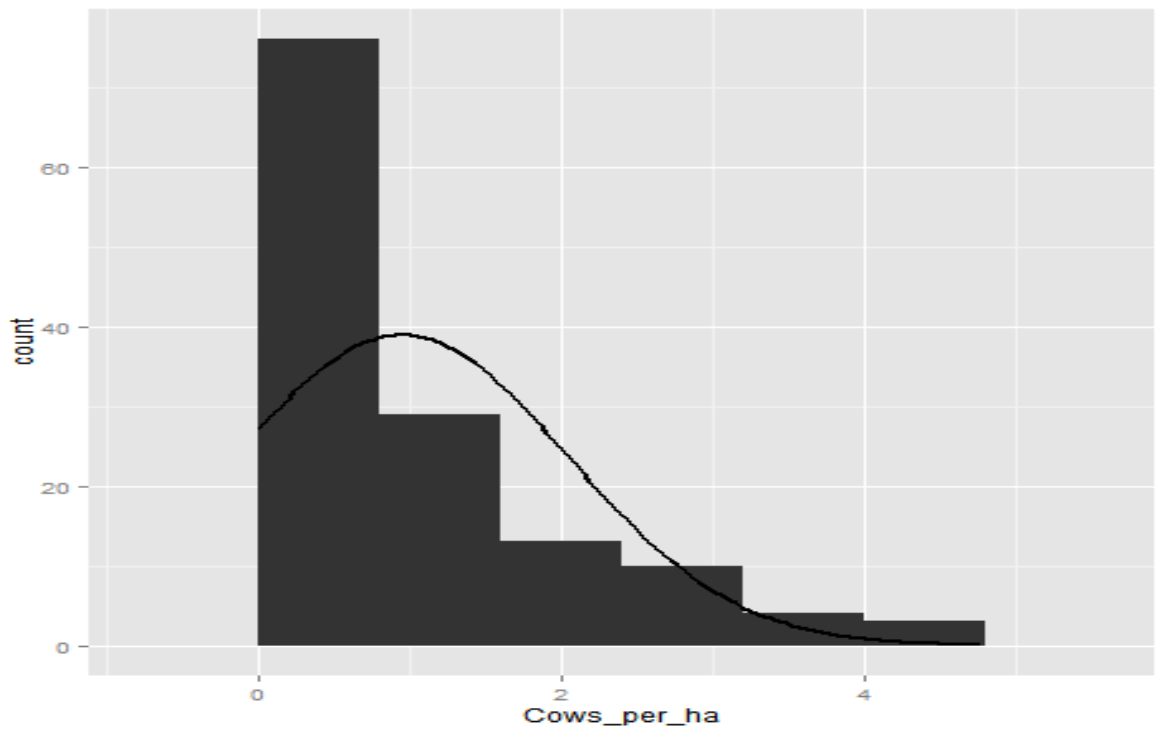

Fig 3. Number of milk cows per hectare in the municipalities of Molise. Year: 2010

In modeling dairy milk production, we must also consider that the density of dairy cows is characterised by a strong positive spatial autocorrelation: municipalities located nearby have similar numbers of dairy cows. This stylised fact is consistent with our theoretical assumption on the role of localisation economies (within-sector externalities).

Taking into account all these features of the distribution of the dependent variable, we will model it by using a Tobit model with Spatial Autoregressive interactions. Let $\mathbf{Y}_{n} \geq 0$ be our censored dependent variable, $\mathbf{X}_{n}$ the set of explanatory variables, and $\mathbf{W}_{n}=\left(w_{i j, n}\right)$, an $n \times n$ matrix whose elements are all non-negative, represent the direct interactions between the municipalities. We will use a binary $\mathbf{W}_{n}$ matrix, so that if there is a direct interaction between local unit $i$ and $j$, then $w_{i j, n}=w_{j i, n} \neq 0$; zero otherwise. As usual, $w_{i i, n}=0 \forall i$. The spatial autoregressive Tobit model can be written in matrix form as

$$
\mathbf{Y}_{n}=\max \left(0, \mathbf{Y}_{n}^{*}\right)=\Phi\left(\rho \mathbf{W}_{n} \mathbf{Y}_{n}+\mathbf{X}_{n} \boldsymbol{\beta}+\boldsymbol{\varepsilon}_{n}\right)
$$

where $\mathbf{Y}_{n}^{*} \equiv \rho \mathbf{W}_{n} \mathbf{Y}_{n}+\mathbf{X}_{n} \boldsymbol{\beta}+\boldsymbol{\varepsilon}_{n}$ is a $n \times 1$ latent variable which is only observed for $\mathbf{Y}_{n} \geq 0$ and censored to 0 otherwise; $\boldsymbol{\beta}$ is a $k \times 1$ vector of parameters associated with the $n \times k$ data matrix $\mathbf{X}_{n}$. This model is a system of nonlinear equations with censored dependent variables. $X u$ and Lee (2014) discuss the conditions for the coherency of this model. We use the SAR Tobit procedure described in their paper to estimate it, using software $\mathrm{R}$.

As mentioned above, the dependent variable, $\mathbf{Y}_{\mathbf{n}}$ (Dairy), is the total milk cow inventory divided by the utilised agricultural area (SAU). Following Roe et al. (2002), Isik (2004) and Larue et al. (2007), we included a spatial lag of the dependent variable $\left(\mathbf{W}_{n} \mathbf{Y}_{n}\right)$ to capture the role of 
localisation externalities, i.e. industry-specific positive spatial externalities. Within the set of explanatory variables, $\mathbf{X}_{\mathrm{n}}$, we included:

( $I$ ) the percentage of forage area as a proxy for the local availability of milk cow feed $($ feed $) ; 15$

(ii) a measure of related variety $(\ln R V)$ that is the logarithm of the Theil index of the number of livestock units, including only "other bovines" and "sheep herds" livestock units;

(iii) the logarithm of the measure of market potential or market accessibility $(\ln$ Market), that is the number of employees in dairy companies.

Following Harris (1954), we measured market potential by multiplying the spatial accessibilityweighting matrix $\mathbf{W}_{n}^{o}=\left(\mathbf{W}_{n}+\mathbf{I}_{n}\right)$, with $\mathbf{I}_{n}$ the identity matrix, by the vector of number of employees in dairy companies:

$$
\text { Market }_{i}=\sum_{j=1}^{n} \frac{M_{j}}{d_{i j}}
$$

where $M_{j}$ is the above mentioned number of employees in dairy companies in each municipality $j$ and $d_{i j}$ is an element of the matrix $\mathbf{W}_{n}^{o}$. It is well known that the market potential function provides an indication of the general proximity of a location (a municipality in our case) in relation to total demand. The market potential of dairy farms in municipality $i$ is higher when demand in surrounding markets (approximated by the number of employees in dairy companies in municipality $i$ as well as in all other municipalities included in the computation) is higher and when access to those markets is better (lower distance between municipality $i$ and the other municipalities). Since the outlet market cannot be confined to the region of Molise, we included in the computation of the market potential the municipalities of the neighbouring regions (Lazio, Abruzzo, Campania and Puglia) (Figure 4, panel A).

As argued in section (3), the geographical distribution of demand is an important explanatory variable of industrial concentration. Thus, empirical analyses of industrial concentration should include a measure of market size or market potential. Nevertheless, this empirical approach is problematic. The key idea of economic geography is indeed that the location of demand is jointly determined by the location of production. This means that the relationship between the geographical concentration of production and the geographical concentration of demand may be characterised by reverse causality. In order to avoid or reduce the consequent endogeneity bias in the estimation of the effect of market size, empirical studies often use instrumental variable approaches. In our case, however, this solution is problematic because there is no SAR Tobit model able to control for endogeneity bias. Thus, we used "sufficiently" lagged values of market potential in order to alleviate the problem, that is we adopted data on the number of employees in dairy companies from the 2000 agriculture census.

Tab 2. Descriptive statistics explanatory variables.

\begin{tabular}{|l|c|c|c|c|c|c|c|}
\hline & Min. & 1st. Qu. & Median & Mean & 3rd. Qu. & Max & Std.dev. \\
\hline Market Potential & -1.54 & -1.35 & -1.22 & -0.82 & -0.68 & 2.85 & 0.95 \\
\hline Local feed production & 0.01 & 0.47 & 0.81 & 1.00 & 1.58 & 2.18 & 0.67 \\
\hline Related variety & 0.01 & 0.87 & 1.06 & 1.00 & 1.20 & 1.43 & 0.28 \\
\hline
\end{tabular}

\footnotetext{
${ }^{15}$ As mentioned in Section 3, the availability of (fertile) land shapes comparative advantages in dairy production. However, we do not need to include a proxy for this production factor in vector $\mathbf{X}_{\mathbf{n}}$, because the dependent variable is normalised by the utilised agricultural area (SAU).
} 
Table 2 provides basic descriptive statistics of these explanatory variables, Table 3 shows correlation values between the same variables, while Figure 4 (panels C-D) highlights their spatial distribution. As for market potential, it is possible to distinguish two "specialised" areas in Alto Molise and in the Southeast. ${ }^{16}$ The local feed production appears localised around the two focused areas reported above. Finally, related variety is concentrated in Alto Molise, where bovine breeding systems are traditionally a little less "industrialised" and specialised.

Tab 3. Correlation between the explanatory variables.

\begin{tabular}{|l|c|c|}
\hline & Local feed production & Related variety \\
\hline Market Potential & 0.167 & 0.271 \\
\hline Local feed production & & 0.108 \\
\hline
\end{tabular}

A)

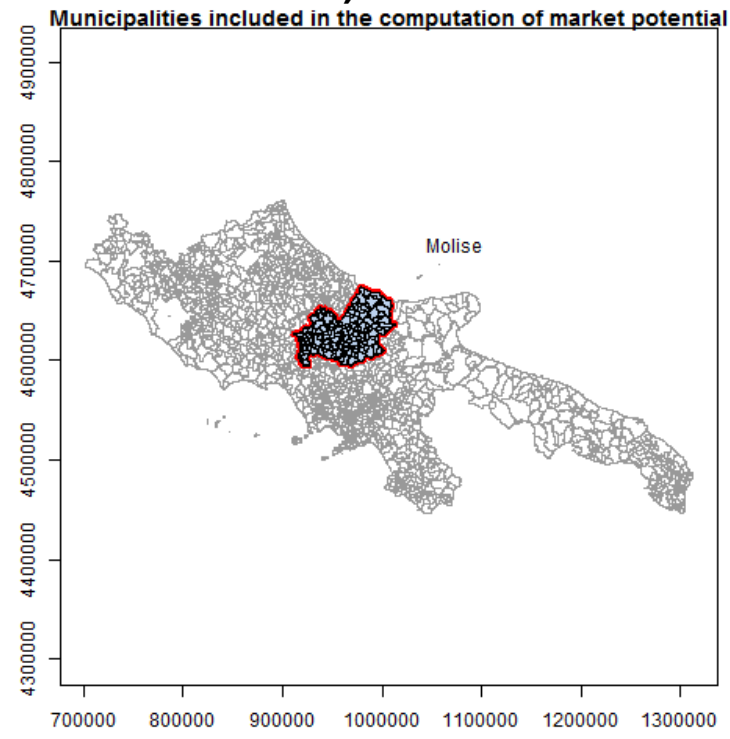

C)

Local feed production

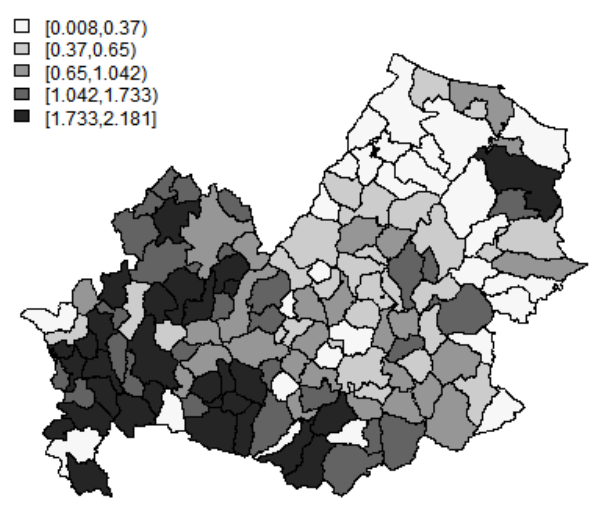

B)

Market potential

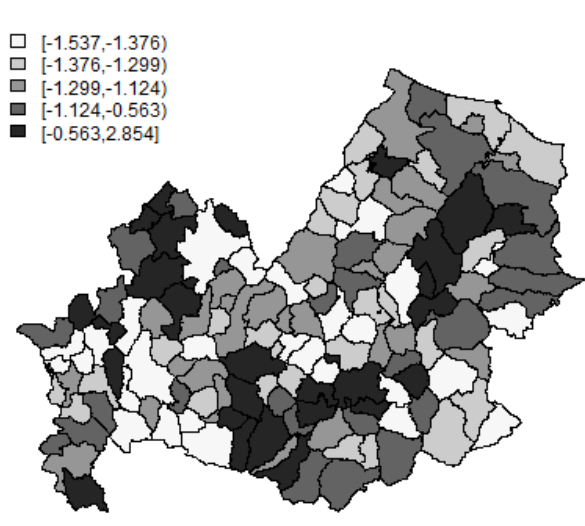

D)

Related Variety

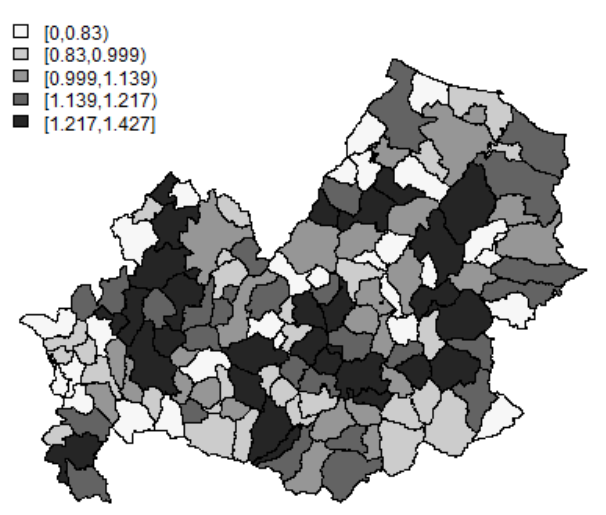

Fig 4. Spatial distribution of explanatory variables.

\footnotetext{
${ }^{16}$ Must be noted that there is also a "pole" towards Basso Molise.
} 


\section{Estimation results}

An initial evaluation of the results obtained can be made, from a statistical point of view, comparing outcomes attained via the SAR Tobit model with those obtained utilising other "applicable" statistical models. Very briefly, it should be recalled that the information utilised is constituted by censored spatial data. Because of the non-random distribution of these data (as indicated by the descriptive analysis reported above), standard requirements for "conventional" regression cannot be effective, in particular for what concerns the independence hypothesis. In general, SAR models are used to overcome these problems and to produce consistent estimates. With regard to the censoring problem, to go beyond well-known problems of "standard" regression, the Tobit model is generally utilised. In general, to deal with these issues the SAR Tobit model seems to provide the best solution.

In Table 4, we compare the results of four competing models: the standard linear OLS model, the linear SAR model, the standard Tobit model, and the SAR Tobit. It clearly emerges that the SAR Tobit model outperforms all the others in terms of statistical plausibility (the log-likelihood is higher), and model fitting (the AIC index is lower).

Tab 4. Estimation results.

\begin{tabular}{|c|c|c|c|c|}
\hline & $\begin{array}{l}\text { Linear model } \\
\text { (OLS) }\end{array}$ & $\begin{array}{c}\text { Linear SAR model } \\
(\mathrm{ML})\end{array}$ & $\begin{array}{l}\text { Tobit model } \\
\text { (ML) }\end{array}$ & $\begin{array}{l}\text { SAR Tobit } \\
\text { (ML) }\end{array}$ \\
\hline Intercept & $\begin{array}{c}0.273 \\
(0.384)\end{array}$ & $\begin{array}{l}-0.005 \\
(0.350)\end{array}$ & $\begin{array}{c}-1.360^{* *} \\
(0.644)\end{array}$ & $\begin{array}{c}-1.467^{\star \star} \\
(0.582)\end{array}$ \\
\hline Market Potential & $\begin{array}{l}0.250^{\star \star} \\
(0.097)\end{array}$ & $\begin{array}{l}0.201^{* *} \\
(0.088)\end{array}$ & $\begin{array}{l}0.302^{\star *} \\
(0.125)\end{array}$ & $\begin{array}{l}0.247^{\star *} \\
(0.114)\end{array}$ \\
\hline Local feed production & $\begin{array}{l}0.389^{* * *} \\
(0.134)\end{array}$ & $\begin{array}{l}0.275^{* *} \\
(0.126)\end{array}$ & $\begin{array}{l}0.432^{* *} \\
(0.185)\end{array}$ & $\begin{array}{l}0.283^{*} \\
(0.165)\end{array}$ \\
\hline Related variety & $\begin{array}{c}0.481 \\
(0.323)\end{array}$ & $\begin{array}{l}0.478^{*} \\
(0.292)\end{array}$ & $\begin{array}{l}1.799^{* \star *} \\
(0.538)\end{array}$ & $\begin{array}{l}1.795^{\star \star \star} \\
(0.520)\end{array}$ \\
\hline Rho & & $\begin{array}{l}0.381^{* * *} \\
(0.089)\end{array}$ & & $\begin{array}{l}0.358^{\star * *} \\
(0.091)\end{array}$ \\
\hline Log-likelihood & -193 & -184 & -189 & -150 \\
\hline AIC & 396 & 380 & 388 & 312 \\
\hline $\begin{array}{l}\text { LM test for residual } \\
\text { autocorrelation }\end{array}$ & & $\begin{array}{c}\text { Test: } 1.241 \\
\text { p-value: } 0.265\end{array}$ & & \\
\hline
\end{tabular}

Notes: Coefficients and standard errors (in parenthesis). Total no. of observations: 135. Left censored observations: 39. Uncensored: 96. Right-censored: 0.

Focusing on the results of the SAR Tobit model, all beta parameters turned out to be statistically significant, but they cannot be interpreted as marginal effects. Like any SAR model, the Tobit SAR model also allows for interdependence among spatial units and corresponds to a long-run equilibrium relation between the response variable and its covariates. The spatial multiplier matrix, $A_{n} \equiv\left(\mathbf{I}_{n}-\rho \mathbf{W}_{n}\right)^{-1}=\mathbf{I}_{n}+\rho \mathbf{W}_{n}+\rho^{2} \mathbf{W}_{n}^{2}+\ldots$, in the reduced form of any SAR model premultiplies both observed and unobserved factors: the outcome in a location $i$ will not only be affected by the exogenous characteristics of $i$, but also by those in any other location $j$ through the inverse spatial transformation. The impact therefore is global. The powers of $\rho$ matching the powers of $\mathbf{W}_{n}$ (higher orders of neighbors) ensure that a distance decay effect is present. Thus, it is customary to distinguish between direct, indirect and total spatial effects. Direct effects measure the impact of a change in regressor $x_{k}$ in region $i$ on the outcome of the same region, while indirect effects measure the impact of a change in regressor $x_{k}$ in region $j$ on the outcome of region $i$. Total marginal effects are simply the sum of direct and indirect effects. The problem with these effects is that, conditional on the model, both direct and indirect effects are specific to 
the pair of "regions" (in our case municipalities) involved $(i, j)$. Thus, average measures are typically used to summarise the results. In the SAR model, the average total marginal effect is computed as $\bar{M}_{\text {tot }}^{k}=(1-\hat{\rho})^{-1} \hat{\beta}_{k}$. The average direct impact is $\bar{M}_{d i r}^{k}=n^{-1} \operatorname{tr}\left[\left(\mathbf{I}_{n}-\rho \mathbf{W}_{n}\right)^{-1} \mathbf{I}_{n} \hat{\beta}_{k}\right]$, while the average indirect impact is $\bar{M}_{\text {ind }}^{k}=\bar{M}_{\text {tot }}^{k}-\bar{M}_{\text {dir }}^{k}$. In order to draw inference regarding the statistical significance of the average direct and indirect effects, LeSage and Pace (2009, p.39) suggested simulating the distribution of the direct and indirect effects using the variancecovariance matrix implied by the ML estimates. Efficient simulation approaches can be used to produce an empirical distribution of all the parameters that are needed to calculate the scalar summary measures. This distribution can be constructed using a large number of simulated parameters drawn from the multivariate distribution of the parameters implied by the $\mathrm{ML}$ estimates.

Marginal effects of the SAR Tobit model are reported in Table 5 and compared with those obtained with the Linear SAR model. The latter seems to overrate market potential and local feed effects and underestimate the effects of related variety.

Tab 5. Marginal effects and simulated z-values (in square brackets).

\begin{tabular}{|c|c|c|c|}
\hline & & Linear SAR & SAR Tobit \\
\hline \multirow[t]{3}{*}{ Market Potential } & Average direct effects & $\begin{array}{l}0.210^{* *} \\
{[2.344]}\end{array}$ & $\begin{array}{l}0.166^{\star *} \\
{[2.152]}\end{array}$ \\
\hline & Average indirect effects & $\begin{array}{c}0.114^{*} \\
{[1.809]}\end{array}$ & $\begin{array}{c}0.088 \\
{[1.153]}\end{array}$ \\
\hline & Average total effects & $\begin{array}{l}0.325^{\star *} \\
{[2.291]}\end{array}$ & $\begin{array}{c}0.254^{*} \\
{[1.990]}\end{array}$ \\
\hline \multirow[t]{3}{*}{ Local feed production } & Average direct effects & $\begin{array}{l}0.288^{\star *} \\
{[2.193]}\end{array}$ & $\begin{array}{c}0.191^{*} \\
{[0.171]}\end{array}$ \\
\hline & Average indirect effects & $\begin{array}{c}0.157^{\star} \\
{[1.951]}\end{array}$ & $\begin{array}{c}0.101 \\
{[1.370]}\end{array}$ \\
\hline & Average total effects & $\begin{array}{l}0.446^{\star *} \\
{[2.274]}\end{array}$ & $\begin{array}{c}0.292^{\star} \\
{[1.650]}\end{array}$ \\
\hline \multirow[t]{3}{*}{ Related variety } & Average direct effects & $\begin{array}{c}0.500^{*} \\
{[1.784]}\end{array}$ & $\begin{array}{l}1.204^{\star * *} \\
{[3.491]}\end{array}$ \\
\hline & Average indirect effects & $\begin{array}{c}0.273 \\
{[1.375]}\end{array}$ & $\begin{array}{l}0.639^{\star *} \\
{[2.000]}\end{array}$ \\
\hline & Average total effects & $\begin{array}{c}0.774^{\star} \\
{[1.676]}\end{array}$ & $\begin{array}{l}1.843^{\star \star *} \\
{[3.043]}\end{array}$ \\
\hline
\end{tabular}

Considering the SAR Tobit model, we first observed that the indirect effect of market potential is not significant. However, it is misleading to interpret this result as absence of spatial spillover effects, because the market potential variable itself is designed in a way as to take account of surrounding effects. The direct and the total effects of market potential instead appeared significant: a $1 \%$ increase in this variable had an impact on the dependent variable of about $0.254 \%$. An analogous situation characterises the variable local feed production. Neighbourhood influences are not significant, and direct effects are rather circumscribed. However, in this case we properly interpreted this result as weak or negligible spatial spillover effects. The estimated total effect is 0.292 with a significant level just above $90 \%$.

Finally, the situation concerning the related variety appears quite different. In this case, average indirect effects are strongly significant, with a value of 0.639 . Direct effects are quite considerable (1.204). Related variety, as a whole, has a marginal effect of 1.843. 


\section{Discussion and conclusions}

The location of dairy milk production in Molise has shown significant changes over the last thirty years, with an increase of spatial concentration in favour of marginal areas. ${ }^{17}$ The estimation results of a SAR Tobit model suggest that all three categories of factors considered in the literature have played a significant role in affecting this spatial pattern even though with different intensities.

On the one hand, local feed and market potential played a limited influence. The forage area in neighbouring districts does not affect indeed the numbers of dairy cows at municipality level. This probably can be related to the limited market of forage, whose production remains largely close to dairy farm "gates". ${ }^{18}$ Moreover, the limited influence of market potential is very likely due to the characteristics of the regional dairy products which are mainly an expression of agricultural traditions.

On the other hand, the impact of related variety seems to be rather high: the presence of other (mainly bovine) breeding farms - both in the same municipality and in adjacent areas - turns out to be a key factor in explaining the agglomeration of dairy farming in Molise. The spatial proximity to "similar" animal production activities is indeed an essential factor of knowledge for milk producers. In other words, the related variety (i.e. agglomeration economies between closely related activities) is an important factor of localisation in this sector, similar to other industries reported in the literature (Boschma and Wenting, 2007).

In short, the empirical results suggest that the presence of dairy farms in less favoured areas is more correlated to the existence of closely related activities and to synergic with other similar types of breeding than to target markets. In this regard, the estimated model captures the spatial linkages and this seems relevant from a spatial perspective. In other words, problems of breeding of dairy cattle in peripheral areas appear connected both to geographical disadvantages and to depletion of nearby breeding activities as a whole. This can be a useful element for planning interventions, not only for Molise region, but also for similar marginal areas.

Our results may also have some relevance from a policy point of view. As pointed out above, current policies, grounded on an institutional approach, try to boost dairy farming using a set of measures focused on market regulation (contracts, etc.). The relatively weak role of market potential estimated with our model may cast some doubts on the validity of this policy framework.

An alternative policy approach could be based on two main strategies consistent with the previous interpretations. The first consists of sustaining breeding diversification by exploiting local traditions ${ }^{19}$. The second consists of supporting specific innovation processes, capable of raising productivity and keeping costs down without sacrificing the quality of the milk ${ }^{20}$.

As a final consideration, it is worth pointing out that our empirical results are conditional on an information set referred to the transition period from milk quotas to market orientation, and we cannot assume that all the adjustments to this important institutional shock have already taken place. It is therefore important to monitor the spatial evolution of the phenomenon under consideration in future studies.

\footnotetext{
17 If centrifugal forces have worked, their effects can have interested areas outside the borders of Molise, also very distant from them.

18 Obviously also in Molise there is a more developed market of concentrated feeding stuffs necessary to complement cattle diets.

19 This could mean, for example, helping farmers to promote productions obtained taking cattle to pasture, benefiting from the "Transhumance path route" (Tratturi) reputation, utilising also local breeds of sheep and goats. This could also concern the construction of tourism-related activities based on the transhumance experiences.

20 These strategies can be pursued, at least in part, through the II pillar of CAP as suggested by the European Parliament.
} 


\section{Acknowledgements}

We would like to thank Andrea Micocci and Simona Zampino who have commented on earlier versions of the paper. This work was supported by the Dipartimento Agricoltura Ambiente Alimenti dell'Università del Molise [DESCLAM Project] and partially funded by Regione Molise.

\section{Academic references}

[1] Bagarani, M. \& Belliggiano, A. (1997). L'industria agro-alimentare molisana. In Tartaglia A., ed., Identificazione e sviluppo di un modello locale: il caso del frumento nel Molise. Campobasso: P. F. RAISA CNR, pp. 39-81.

[2] Bagarani, M., Belliggiano, A., levoli, C. \& Scardera, A. (2014). Analisi di contesto del Programma di Sviluppo Rurale 2014-2020 [Research Report], Studio dell'Università del Molise per conto dell'ARSIAM.

[3] Beaudry, C. \& Schiffauerova, A., (2009). Who's right, Marshall or Jacobs? The localization versus urbanization debate. Research Policy 38(2), 318-337. DOI: 10.1016/j.respol.2008.11.010.

[4] Ben Arfa, N., Rodriguez, C., Daniel, K. \& Shonkwiler, J. S. (2009). Spatial Structure of the French dairy sector: a spatial HAC estimation [Paper presented at 3èmes journées de recherches en sciences sociales INRA SFER CIRAD 09, 10 \& 11 décembre, Montpellier].

[5] Ben Arfa, N., Rodriguez, C., Daniel, K. \& Shonkwiler, S. J. (2010). Spatial Structure of Agricultural Production in France: Role of the Common Agricultural Policy [OECD Workshop on the Disaggregated Impacts of CAP Reform, 10-11 March].

[6] Bichler, B., Haring, A. M., Dabbert, S. \& Lippert, C. (2005). Determinants of Spatial Distribution of Organic Farming in Germany [a paper read at the conference Researching Sustainable Systems, Adelaide].

[7] Boschma, R. A. (2005). Editorial. Role of proximity in interaction and performance. Conceptual and empirical challenges. Regional Studies 39(1), 41-45. DOI: $10.1080 / 0034340052000320878$.

[8] Boschma, R. A. \& Wenting, R. (2007). The spatial evolution of the British automobile industry: Does location matter? Industrial and Corporate Change 16(2), 2213-238. DOI: $10.1093 / \mathrm{icc} / \mathrm{dtm} 004$.

[9] Boschma, R. A. \& lammarino, S. (2009). Related Variety, Trade Linkages and Regional Growth. Economic Geography 85(3), 289-311. DOI: 10.1111/j.1944-8287.2009.01034.x.

[10] Boschma, R. \& Frenken, K. (2011). The emerging empirics of evolutionary economic geography, Journal of Economic Geography 11(2), 295-307. DOI: 10.1093/jeg/lbq053.

[11] Duranton, G. \& Puga, D. (2004). Micro-foundations of urban agglomeration economies. In Henderson, J. V. \& Thisse, J. F., eds., Handbook of Regional and Urban Economics (pp. 2063-2117). Amsterdam: Elsevier.

[12] Duranton, G. \& Puga, D. (2001). Nursery Cities: Urban Diversity, Process Innovation, and the Life Cycle of Products. The American Economic Review 91(5), 1454-1477. DOI: 10.1257/aer.91.5.1454.

[13] Forti, R. \& Henrard, M., eds. (2016). Agriculture, forestry and fishery statistics, 2015 edition, Luxembourg: Publications Office of the European Union. DOI: 10.2785/906420.

[14] Fasolino, G. \& levoli, C. (1997). Il grano duro nel Molise: l'evoluzione dell'intervento regionale e l'impatto della nuova politica comunitaria. In Tartaglia, A., (ed.), (1997) Identificazione e sviluppo di un modello locale: il caso del frumento nel Molise. RAISA CNR, Campobasso, Arti Grafiche La Regione, pp. 243-265. 
[15] Frenken, K., Van Oort, F. G. \& Verburg, T. (2007). Related variety, unrelated variety and regional economic growth. Regional Studies, 41(5), 685-697. DOI: $10.1080 / 00343400601120296$.

[16] Glaeser, E. L., Kallal, H. D., Scheinkman, J. A. \& Shleifer, A. (1992). Growth in Cities, The Journal of Political Economy 100(6), 1126-1152. DOI: 10.1086/261856.

[17] Henderson, V., Kuncoro, A. \& Turner, M. (1995). Industrial development in cities. Journal of Political Economy, 103(5), 1067-1090. DOI: 10.1086/262013.

[18] Isik, M. (2004). Environmental Regulation and the Spatial Structure of the US Dairy Sector. American Journal of Agricultural Economics 86, 949-962. DOI: 10.1111/j.00029092.2004.00645.x.

[19] Jacobs, J. (1969). The Economy of Cities. New York, Random House.

[20] Karelakis, C., Zafeiriou, E., Galanopoulos, K. \& Koutroumanidis, T. (2013). Natural resources in regional and rural development: moving from public perceptions to policy action, New Medit 12(1), 56-64.

[21] Läpple, D. \& Kelley, H. (2015). Spatial dependence in the adoption of organic drystock farming in Ireland. European Review of Agricultural Economics 42(2), 315-337. DOI: $10.1093 /$ erae/jbu024.

[22] Larue, S., Abildtrup, J. \& Schmitt, B. (2007). Modeling the Spatial Structure of Pig Production in Denmark [Paper presented at Annual North American meetings of the Regional Science Association International, Nov 2007, Savannah].

[23] LeSage, J. \& Pace, R. K. (2009). Introduction to Spatial Econometrics. London: Chapman and Hall.

[24] MacDonald, J. M., O’Donoghue, E. J., McBride, W. D., Nehring, R. F., Sandretto, C. L. \& Mosheim, R. (2007). Profits, Costs, and the Changing Structure of Dairy Farming [Economic Research Report 47], Washington, DC: United States Department of Agriculture.

[25] Neffke, F. M. H, Henning, M. \& Boschma, R. A. (2011). How do regions diversify over time? Industry relatedness and the development of new growth paths in regions. Economic Geography 87(3), 237-265. DOI: 10.1111/j.1944-8287.2011.01121.x.

[26] Paladino, M. \& Scardera, A. (2014). L'agricoltura del Molise. Roma: INEA.

[27] Peterson, H. H. (2002). Geographic Changes in U.S. Dairy Production [Paper presented at the Annual Meeting of the American Agricultural Economics Association, Long Beach, July 28-31].

[28] Qu, X., Lee, L. (2013). Locally most powerful tests for spatial interactions in the simultaneous SAR Tobit model. Regional Science and Urban Economics. 43(2), 307-321. DOI: 10.1016/j.regsciurbeco.2012.07.010.

[29] Roe, B., Irwin, E. G. \& Sharp, J. (2002). Pig in Space: Modeling the spatial structure of hog production in traditional and nontraditional production regions. American Journal of Agricultural Economics 84(2), 259-278. DOI: 10.1111/1467-8276.00296.

[30] Rosenthal, S. S. \& Strange, W. C. (2004). Evidence on the nature and sources of agglomeration economies. In Henderson, J. V. \& Thisse, J.-F., eds., Handbook of Urban and Regional Economics, vol. 4 (pp. 2119-2172). Amsterdam: Elsevier.

[31] Thornton, P. K. (2010). Livestock production: recent trends, future prospects. Philosophical Transaction of the Royal Society B 365, 2853-2867. DOI: 10.1098/rstb.2010.0134.

[32] Wieck, C. \& Mosnier, C. (2010). Determinants of spatial dynamics of dairy production: a review, Agricultural and Resource Economics [Discussion Paper 2], Institute for Food and Resource Economics University of Bonn. 
[33] Wieck, C. \& Mosnier, C. (2011). Dynamiques régionales de la production laitière en France, en Allemagne et au Royaume-Uni. Économie Rurale 332, 132-146. DOI: $10.4000 /$ economierurale.3748.

[34] Wieck, C. \& Mosnier, C. (2011). Determinants of the spatial dynamics of regional dairy production systems [Paper prepared for presentation in the Organized Session "Spatial competition in the dairy sector" at the EAAE 2011 Congress "Change and Uncertainty", August 30 to September 2, ETH Zurich].

[35] Wollni, M. \& Andersson, C. (2014). Spatial patterns of organic agriculture adoption: Evidence from Honduras. Ecological Economics 97, 120-128. DOI: 10.1016/j.ecolecon.2013.11.010.

[36] Xingbai, X. \& Lee L. (2015). Maximum likelihood estimation of a spatial autoregressive Tobit model, Journal of Econometrics 188(1), 264-280. DOI: 10.1016/j.jeconom.2015.05.004.

[37] Zimmermann, A. \& Heckelei, T. (2012). Structural Change of European Dairy Farms A Cross-Regional Analysis. Journal of Agricultural Economics 63(3), 576-603. DOI: 10.1111/j.1477-9552.2012.00355.x.

Other sources

[38] CEAS Consultants (Wye) Ltd Centre for European Agricultural Studies and The European Forum on Nature Conservation and Pastoralism (2000), The Environmental Impact of Dairy Production in the EU: Practical Options for the Improvement of the Environmental Impact Final Report for European Commission (DGXI). 